\title{
SARS-CoV-2 infection in a pediatric patient with cystic fibrosis
}

\author{
Jackelyn S. Páez-Velásquez ${ }^{1 *}$, Ilse E. Romero-Uribe ${ }^{2}$, María F. Castilla-Peón ${ }^{3}$, \\ José L. Lezana-Fernández ${ }^{4}$, and Adrián Chávez-López² \\ ${ }^{1}$ Servicio de Pediatría; ${ }^{2}$ Servicio de Terapia Intensiva; ${ }^{3}$ Dirección de Investigación; ${ }^{4}$ Servicio de Neumología. Hospital Infantil de México Federico \\ Gómez, Mexico City, Mexico
}

\begin{abstract}
Background: Cystic fibrosis (CF) is a potentially mortal disease characterized by a chronic pulmonary disease with persistent airway infection. Children with this disease are more susceptible to respiratory infections due to the limitation in mucociliary transport and anatomical disruption of the bronchial tree. SARS-CoV-2 causes COVID-19, a respiratory illness related to exacerbations of chronic pulmonary pathologies in children, such as CF and asthma. There are not enough case reports on pediatric patients with SARS-CoV-2 infection and CF, for which we share our experience. Case report: $A$ 22-month-old male patient diagnosed with CF presented in the hospital with cough, fever, and increased respiratory work. The patient received supplemental oxygen and antibiotic and antiviral therapy. Positive results for type $B$ influenza and RT-PCR (reverse transcription-polymerase chain reaction) for SARS-CoV-2 were obtained. Due to the persistence of respiratory difficulty, high-flow therapy was initiated, with a good response. After an episode of hypoxemia, bradycardia, and increased respiratory work secondary to accumulated secretions, orotracheal intubation and invasive mechanical ventilation were performed. The patient evolved with clinical and gasometric improvement. After 10 days of in-hospital antibiotic management with adequate clinical evolution, the patient was discharged to complete oral treatment and home isolation. Conclusions: We present a case of chronic respiratory disease and SARS-CoV-2 infection with severity criteria in a pediatric patient. The evolution was favorable with timely support management and antibiotic therapy in a third-level hospital.
\end{abstract}

Key words: COVID-19. SARS-CoV-2. Coronavirus. Cystic fibrosis.

\section{Infección por SARS-CoV-2 en un paciente pediátrico con fibrosis quística}

\section{Resumen}

Introducción: La fibrosis quística es una afección potencialmente mortal caracterizada por enfermedad pulmonar crónica con infección persistente de las vías aéreas. Los niños con esta enfermedad son más susceptibles a infecciones respiratorias debido a la limitación en el transporte mucociliar y la distorsión anatómica del árbol bronquial. El SARS-CoV-2 (coronavirus tipo 2 del síndrome agudo respiratorio grave) es el virus causante de la COVID-19, enfermedad respiratoria que puede estar relacionada con exacerbaciones de patologías pulmonares crónicas en niños, como la fibrosis quística y el asma. No hay suficientes reportes de casos de pacientes pediátricos con infección por SARS-CoV-2 y fibrosis quística, por lo cual se comparte la presente experiencia. Caso clínico: Paciente de sexo masculino de 22 meses de edad con diagnóstico de fibrosis quística que presentó tos, fiebre y aumento en el trabajo respiratorio. A su ingreso se inició

\section{Correspondence:}

*Jackelyn Stephanny Páez-Velásquez

E-mail: stefy0.9@ hotmail.com
Date of reception: 11-07-2020

Date of acceptance: 14-08-2020

DOI: 10.24875/BMHIM.20000216
Available online: $24-02-2021$

Bol Med Hosp Infant Mex. 2021;78(1):29-33

www.bmhim.com (http://creativecommons.org/licenses/by-nc-nd/4.0/) 
manejo con oxígeno suplementario y tratamiento antibiótico y antiviral. Se obtuvo prueba positiva para influenza tipo $B$ y para SARS-CoV-2 por RT-PCR (reacción en cadena de la polimerasa de transcriptasa inversa). Ante un episodio de hipoxemia, bradicardia y mayor trabajo respiratorio, requirió intubación orotraqueal y ventilación mecánica invasiva. El paciente evolucionó con mejoría clínica y gasométrica. Después de 10 días de manejo antibiótico intrahospitalario, con adecuada evolución clínica, egresó para completar tratamiento por vía oral y aislamiento en casa. Conclusiones: Se presenta el caso de un paciente pediátrico con enfermedad respiratoria crónica de base e infección por SARS-CoV-2 con criterios de gravedad. El paciente evolucionó favorablemente con el manejo de soporte oportuno y terapia de antibióticos en un hospital de tercer nivel.

Palabras clave: COVID-19. SARS-CoV-2. Coronavirus. Fibrosis quística.

\section{Introduction}

Coronaviruses (CoVs) are members of the Coronaviridae family and are classified into four groups: alpha, beta, delta, and gamma coronaviruses. Those that mainly circulate in humans are four types: HCoV2229E, -HKU1, -NL63, and -OC43'1.

CoVs display a high capacity to mutate and recombine. In humans, these pathogens mainly cause respiratory symptoms, ranging from viral rhinopharyngitis to acute respiratory distress syndrome (ARDS) coagulopathy, multiple organ failure, and death ${ }^{2}$. Furthermore, CoVs have been associated with exacerbations of chronic lung diseases such as cystic fibrosis (CF) and asthma in children ${ }^{1}$.

On December 31, 2019, the first report of atypical pneumonia cases associated with SARS-CoV-2 (severe acute respiratory syndrome coronavirus type 2), a new beta-coronavirus, was announced in Wuhan. This virus has spread exponentially, becoming a pandemic. The term COVID-19 is used to identify the clinical disease caused by SARS-CoV-23.

Cystic fibrosis ${ }^{4,5}$ is a life-threatening autosomal recessive disease, common in the Caucasian population, with a frequency of 1 in 4000 live newborns in the US. It is characterized by chronic lung disease with persistent airway colonization or infection, exocrine pancreatic insufficiency, elevated sweat chloride, and infertility in men. Children with this disease are more susceptible to respiratory infections due to limited mucociliary transport and anatomical distortion of the bronchial tree, facilitating the accumulation of secretions. In a study conducted in Sao Paulo, Brazil, between 2006 and 2007 on the impact of coronaviruses in pediatric CF patients ${ }^{6}$, the authors found that the patient's response may depend on the baseline lung function. Thus, if deteriorated, it predisposes to a greater risk of exacerbation? Another hypothesis is that the SARS coronavirus and HcoV-NL-63 use the angiotensin-converting enzyme 2 (ACE2) receptor as the main pathway of binding and entry. However, a substantial reduction in the expression of this enzyme on cell surfaces after infection can also be a determining factor in the severity of $\operatorname{ARDS}^{7,8}$. It was also observed that the genetic polymorphism of ACE2 expression is associated with greater severity of lung disease ${ }^{9}$. Unfortunately, this study failed to identify a significant association of coronavirus infections with CF respiratory exacerbations and hospital admissions.

Few cases of adult patients with CF and COVID-19 have been recorded in Europe ${ }^{5}$. Apparently, there is no effect on the severity or protective factors, such as prophylactic antibiotics, that have been identified. In addition, no pediatric cases with CF and SARS-CoV-2 infection have been reported so far. This report shares our experience in an infant with this underlying pathology to broaden the knowledge about the disease and optimize the management of pediatric patients with similar pathologies.

\section{Clinical case}

We present the case of a one-year-and-10-month-old male patient from Veracruz, Mexico, with a history of three non-serious episodes of community-acquired pneumonia before 6 months of age and a diagnosis of CF by the sweat chloride test. The patient came for evaluation with a history of upper airway infection 14 days before admission, followed by a $48 \mathrm{~h}$ sudden-onset of symptoms consisting of wet, non-expectorant, non-progressive cough of short accesses, non-cyanotic, non-breathless, and vomiting. This clinical picture was associated with fever, quantified on three occasions, with a maximum peak of $38{ }^{\circ} \mathrm{C}$ and an approximate duration of 1 hour, in addition to respiratory distress $24 \mathrm{~h}$ before admission. Fever was controlled with paracetamol (acetaminophen).

On admission to the emergency service, the aerosol protection protocol was started. The patient was transferred to the area assigned for patients with suspected SARS-CoV-2 infection. Clinically, the patient presented tachycardia, polypnea, fever $\left(38.2^{\circ} \mathrm{C}\right)$, and an arterial 
$\mathrm{O}_{2}$ saturation of $87 \%\left(\mathrm{FiO}_{2}\right.$ 0.21). Physical examination revealed a symmetric chest with increased anteroposterior diameter, intercostal and suprasternal retraction, and thoracoabdominal dissociation. Auscultation revealed bilateral basal crepitus. Oxygen therapy with a non-rebreathing mask was started, with a $10 \mathrm{~L} / \mathrm{min}$ flow rate. A partial response was evidenced by a decrease in tachycardia to $105 / \mathrm{min}$ and arterial oxygen saturation of $98 \%$, but persistent polypnea. Diagnosis of cystic fibrosis exacerbation and suspected COVID-19 was integrated. Fasting, accompanied by base solutions, was indicated for the patient. Antimicrobial management started with ceftriaxone, amikacin, azithromycin, and oseltamivir.

In the chest X-ray on admission (Fig. 1), pulmonary parenchyma showed alveolar infiltrates in the projection of segment 5 of the right lung, with no areas of consolidation. Blood analysis showed leukocytosis with neutrophilia and thrombocytosis. The arterial blood gas data were $\mathrm{pH} 7.39$, carbon dioxide partial pressure $\left(\mathrm{pCO}_{2}\right) 36.2 \mathrm{mmHg}$, oxygen partial pressure $\left(\mathrm{pO}_{2}\right)$ $156 \mathrm{mmHg}$, bicarbonate concentration $\left(\mathrm{HCO}_{3}\right)$ $21.9 \mathrm{mmol} / \mathrm{L}$, oxygen saturation $\left(\mathrm{sO}_{2}\right) 98.7 \%$, lactate $0.8 \mathrm{mmol} / \mathrm{L}$, Kirby index $195 \mathrm{mmHg}$, and fraction of inspired oxygen $\left(\mathrm{FiO}_{2}\right) 28 \%$. Two peripheral blood cultures from different puncture sites were analyzed. In addition, a pharyngeal swab culture, a respiratory virus panel, and a reverse transcriptase-polymerase chain reaction (RT-PCR) test for SARS-CoV-2 were performed. Six hours later, positive results for SARSCoV-2 and a viral panel for influenza type B were received. Therefore, laboratory studies were expanded.

As the patient displayed breathing difficulties, we decided on intensive care admission for non-invasive ventilation management and high-flow therapy modality at $2 \mathrm{~L} / \mathrm{kg}$ with $\mathrm{FiO}_{2} 50 \%$, thus decreasing respiratory work. Furthermore, a base treatment with dornase alfa was added. During the evolution, the patient presented increased bronchorrhea, which caused upper respiratory failure due to obstruction, for which orotracheal intubation was decided (Fig. 2 and 3). The ventilatory test showed a mixed pattern: peak pressure, $21 \mathrm{~cm}$ $\mathrm{H}_{2} \mathrm{O}$; plateau pressure, $14 \mathrm{~cm} \mathrm{H}_{2} \mathrm{O}$; transpulmonary pressure, $7 \mathrm{~cm} \mathrm{H}_{2} \mathrm{O}$; compliance, 0.75; and positive pressure at the end of expiration (autoPEEP), 0.7. As the patient showed good evolution, extubation was programmed at 12 hours from the start (Fig. 4), and a high flow device was restarted.

At $96 \mathrm{~h}$ after admission, high-flow parameters decreased, and we started feeding the patient through a nasogastric tube. The following day, a low-flow device

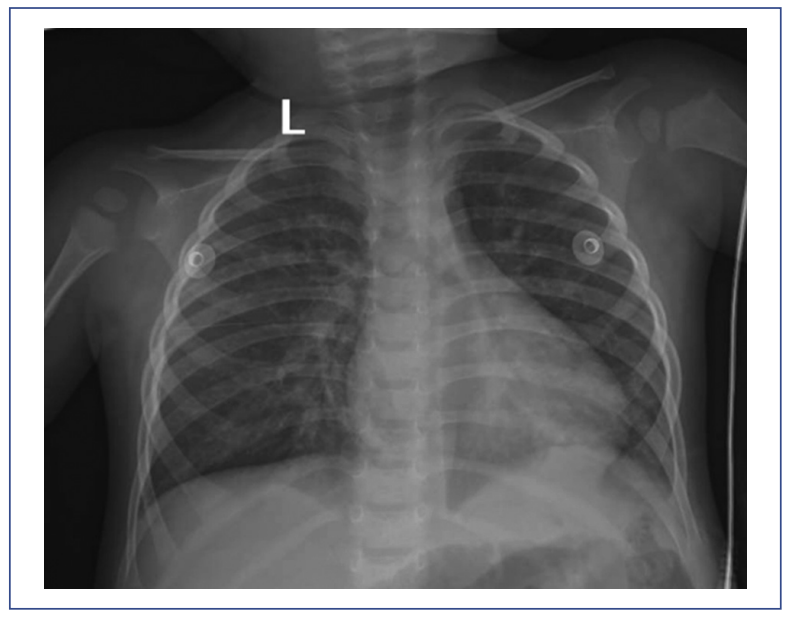

Figure 1. Portable anteroposterior chest X-ray. On admission, ten bilateral intercostal spaces are observed, central trachea without enlarged areas, without cardiomegaly, pulmonary parenchyma with few alveolar infiltrates in the projection of segment 5 of the right lung, without areas of consolidation.

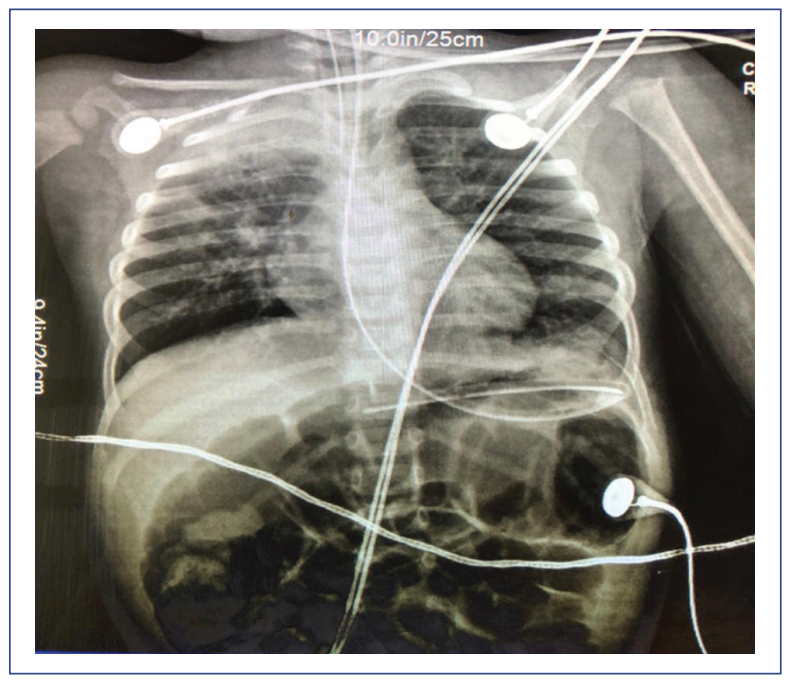

Figure 2. Portable anteroposterior chest X-ray. Eight bilateral intercostal spaces are observed, with a tendency to horizontality, central trachea without widening areas, with an endotracheal device, right lung parenchyma with alveolar infiltrates in the right segments 3, 4, and 5. Right lung parenchyma with few alveolar infiltrates in segment 3.

was placed with adequate tolerance until its removal. A bronchial secretion culture report was positive for two multisensitive morphotypes of Pseudomonas aeruginosa, for which the biconjugated antibiotic treatment was continued. As the patient showed good clinical evolution, it was decided to give outpatient management 12 days after admission, maintaining preventive isolation. Eighteen days after the symptoms began, an 


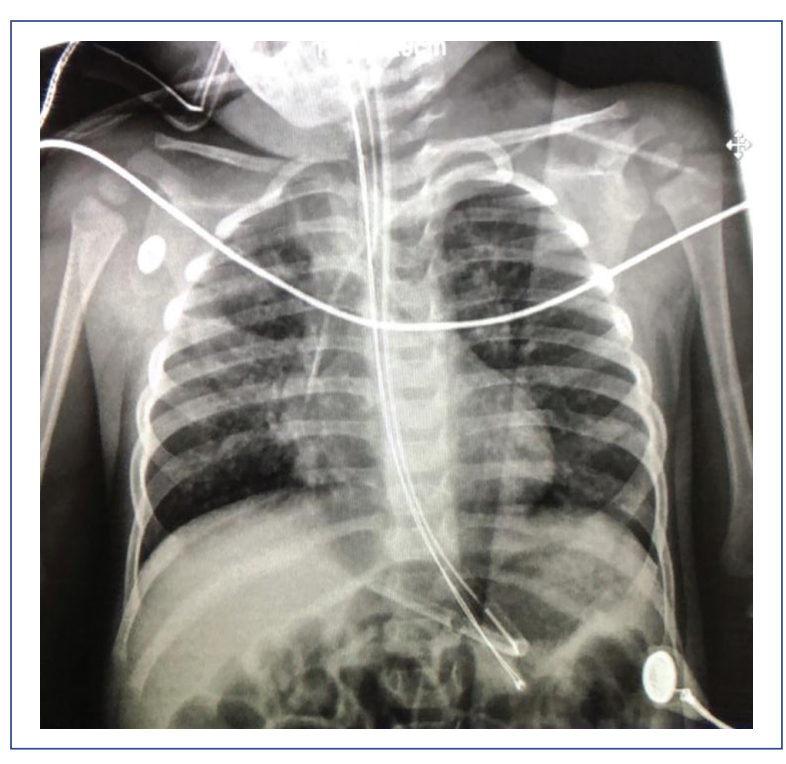

Figure 3. Portable anteroposterior chest X-ray. After central venous catheter placement, an image suggestive of atelectasis in segments 1 and 3 of the right lung parenchyma is observed compared to the previous image. Also, a central venous device with a tip is observed at the level of the right atrium.

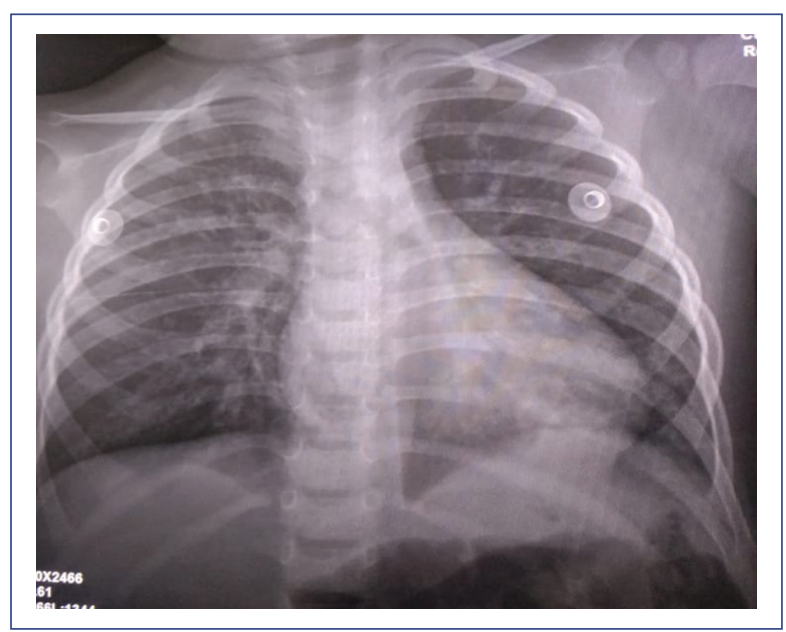

Figure 4. Portable anteroposterior chest X-ray after extubation. In the right lung parenchyma, alveolar infiltrates are observed in segments 3, 4, and 5 right and bronchiectasis in segment 5 . Left lung parenchyma with few alveolar infiltrates in segment 3.

RT-PCR test for SARS-CoV-2 was performed, which was negative. In the follow-up 30 days after discharge, the patient was asymptomatic and in good general condition. Of the seven people with whom the patient lives, only the mother showed respiratory symptoms
14 days before admission. However, the rest of his contacts were not screened for SARS-CoV-2 and no further hospitalization was required during the case surveillance. Besides, all communication was held by telephone until discharge. Thirty days after discharge, the patient was reassessed and found in good general conditions, with a negative RT-PCR test for SARS-CoV-2.

\section{Discussion}

CF is an autosomal recessive hereditary disease caused by mutations located on chromosome 7 , which encodes a protein known as CFTR (CF Transmembrane Conductance Regulator), which functions as a chloride channel in epithelial membranes ${ }^{10-12}$. The alterations in CFTR reduce the periciliary fluid in the bronchial epithelium cells that alter mucociliary transport, causing the retention of thick and dehydrated secretions and subsequent infection by bacterial pathogens. The persistent bacterial infection causes massive migration of neutrophils into the airways and a host response with high levels of pro-inflammatory cytokines (interleukin 8) and the release of neutrophil enzymes such as elastase and myeloperoxidases. This altered inflammatory response is complex and involves multiple stimuli, cells, signaling pathways, eicosanoids, cytokines, and leukotrienes. The cascade of inflammatory events, together with the alteration in the innate immune response (mucociliary function), theoretically would not increase the risk of SARS-CoV-2 infection in CF patients but could cause a more severe course of the disease.

The present case shows a pediatric patient's evolution with a CF history and SARS-CoV-2 infection, which presented severity criteria described by Carlotti et al. ${ }^{13}$. These authors also mentioned gastrointestinal alterations, encephalopathy, myocarditis, kidney failure disease, coagulopathies, and multiorgan failure. Therefore, it was not considered appropriate to start the management currently carried out in adults with other antivirals, antimalarial, or macrolides ${ }^{14}$. Despite this, the patient favorably evolved when managed with the Intensive Care Unit's standard protocols of a tertiary hospital. It is important to highlight that non-invasive mechanical ventilation through high-flow nasal tips was carried out in an isolated room and with all the personnel's precautionary measures.

Finally, our primary recommendation is prevention. As has been observed, the low prevalence of COVID-19 in patients with $\mathrm{CF}^{5}$ reported in Europe is possibly a reflection of reducing social contact and the use of preventive measures. However, it is essential to emphasize to the families the awareness regarding maintaining adequate 
adherence to the indicated preventive measures and avoid contagion in the pediatric population. A greater risk of complications, morbidity, and mortality secondary to viral infections has been reported in children. Through social networks and telephone calls with families, especially in respiratory, cardiovascular, immunological, and oncological patients, preventive measures, and isolation were reinforced at the Hospital Infantil de México Federico Gómez from the beginning of the contingency. The Pediatric Pulmonology team canceled control appointments in person, initiated telephone communication for clinical follow-up, provided recommendations, detected alarm signs, and provided psychological support. Particular emphasis was placed on this patient's mother in continuing the management with pulmonary physiotherapy at home to avoid exacerbations.

Due to the rapid SARS-CoV-2 spread worldwide, it is essential to share the experience from different hospitals in contact with these patients to improve knowledge regarding the clinical characteristics, evolution, treatment, and prognosis. Since literature case reports are mainly in adults, it is beneficial for pediatric centers to report cases on children who require hospitalization and present underlying pathologies that may generate more severe symptoms and slower recovery. With the present case, we seek to illustrate the evolution in a pediatric patient with a CF history and SARS-CoV-2 infection, which did not present with severity criteria and favorably evolved when managed with the standard protocols of Intensive Therapy of a tertiary level hospital.

Therefore, the recommendation is to continue to report pediatric cases since there has been a different evolution than the adult population. Besides, we know that trying to extrapolate the diagnostic results and management can lead to adverse outcomes.

\section{Ethical disclosures}

Protection of human and animal subjects. The authors declare that no experiments were performed on humans or animals for this study.

Confidentiality of data. The authors declare that they have followed the protocols of their work center on patient data publication.

Right to privacy and informed consent. The authors have obtained the written informed consent of the patients or subjects mentioned in the article. The corresponding author has this document.

\section{Conflicts of interest}

The authors declare that they have no conflicts of interest.

\section{Funding}

No funding was received.

\section{Acknowledgments}

The authors would like to thank our family, children, and the Hospital Infantil de México Federico Gómez.

\section{References}

1. Zimmermann $P$, Curtis $N$. Coronavirus infections in children including COVID-19: an overview of the epidemiology, clinical features, diagnosis, treatment and prevention options in children. Pediatr Infect Dis J. 2020;39:355-68.

2. Woo PC, Lau SK, Chu CM, Chan K, Tsoi H, Huang Y, et al. Characterization and complete genome sequence of a novel coronavirus, coronavirus HKU1, from patients with pneumonia. J Virol. 2005;79:884-95.

3. World Health Organization. Coronavirus Disease 2019 (COVID-19). Situation Report-32. Ginebra: World Health Organization; 2020. Available from: https://www.who.int/docs/default-source/coronaviruse/situation-reports/20200221-sitrep-32-covid-19.pdf?sfvrsn=4802d089_2.

4. Farrell PM, White TB, Ren CL, Hempstead S, Accurso F, Derichs N, et al. Diagnosis of cystic fibrosis: consensus guidelines from the Cystic Fibrosis Foundation. J Pediatr. 2017;181S:S4-15.e1.

5. Colombo A, Burguel PR, Gartner S, van Koningsbruggen-Rietschel S, Naehrlich L, Sermet-Gaudelus I, et al. Impact of COVID-19 on people with cystic fibrosis. Lancet Respir Med. 2020;8:e35-6.

6. da Silva Filho LV, Zerbinati RM, Tateno AF, Vilas BL, Buarque de Almeida M, Levi JE, et al. The differential clinical impact of human coronavirus species in children with cystic fibrosis. J Infect Dis. 2012;206:384-8.

7. Wevers BA, van der Hoek L. Renin-angiotensin system in human Coronavirus pathogenesis. Future Virol. 2010;5:145-61.

8. Druker DJ. Coronavirus infections and Type 2 diabetes-shared pathways with therapeutic implications. Endocr Rev. 2020;41:bnaa011.

9. Arkwright PD, Pravica V, Geraghty PJ, Super M, Webb AK, Schwarz M, et al. End-organ dysfunction in cystic fibrosis: association with angiotensin I converting enzyme and cytokine gene polymorphisms. Am J Respir Crit Care Med. 2003;167:384-9.

10. Matsui H, Grubb BR, Tarran R, Randell SH, Gatzy JT, Davis CW, et al. Evidence for periciliary liquid layer depletion, not abnormal ion composition, in the pathogenesis of cystic fibrosis airways disease. Cell. 1998; $95: 1005-15$.

11. Roesch EA, Nichols DP, Chmiel JF. Inflammation in cystic fibrosis: an update. Pediatr Pulmonol. 2018;53:S30-50.

12. Nichols DP, Chmiel JF. Inflammation and its genesis in cystic fibrosis. Pediatr Pulmonol. 2015;S40:S39-56.

13. Carlotti AP, de Carvalho WB, Johnston C, Souza RI, Figuereido DA. COVID-19 diagnostic and management protocol for pediatric patients. Clinics (Sao Paulo). 2020;75:e1894.

14. Sanders JM, Monogue ML, Jodlowski TZ, Cutrell JB. Pharmacologic treatments for coronavirus disease 2019 (COVID-19). A review. JAMA. 2020;323:1824-36. 